\title{
Inhibition of symbiote fungus of the leaf cutter ant Atta sexdens by secondary metabolites from the bacterium Xenorhabdus szentirmaii associated with entomopathogenic nematodes
}

\author{
Inibição do fungo simbionte da formiga-cortadeira Atta sexdens \\ por metabólitos secundários da bactéria Xenorhabdus szentirmaii \\ associada a nematoides entomopatogênicos
}

\author{
Julie Giovanna Chacon Orozco ${ }^{1}$ D, Luis Garrigós Leite' ${ }^{1}$, Bruna Cristina Custódio² ${ }^{\mathbb{D}}$, \\ Raphael Satochi Abe da Silva', Ana Gabriele Barbosa Casteliani', Raphael Vacchi Travaglini ${ }^{3 *}$ (iD
}

\begin{abstract}
Leaf-cutter ants (Hymenoptera: Formicidae) have evolved as dominant herbivores on the American continent. These social insects remove the leaves of economically important plant species to maintain their colony's food reserves, the symbiotic fungus Leucocoprinus gongylophorus, a basidiomycete. Such fungus can be used for applications of fungicide molecules from metabolites generated by symbiont bacteria (Xenorhabdus and Photorhabdus) from entomopathogenic nematodes (Steinernema and Heterorhabditis). Through isolation and multiplication in tryptic soy broth (TSB) medium of the bacteria Xenorhabdus szentirmaii isolated PAM 25, we conducted laboratorial tests using treatments with 10,25 , and $50 \%$ of the metabolites obtained in the sixth day of cultivation. The treatments were centrifuged and filtered to generate a supernatant, which was diluted in potato + dextrose + agar (PDA), to verify the consequences of exposure to the fungus L. gongylophorus in Petri dishes. To confirm metabolite efficiency, the control treatments in PDA only and mixed (PDA+TSB) media were conducted simultaneously for 14 days. We observed total inhibition of the symbiont fungus in both the 25 and 50\% dilutions during the first days of the tests. Our results support that these metabolites have inhibitory effect on the development of symbiont fungus of leaf-cutter ants.
\end{abstract}

KEYWORDS: alternative control; Leucocoprinus gongylophorus; entomopathogenic nematodes.
RESUMO: As formigas-cortadeiras (Hymenoptera: Formicidae) evoluíram estabelecendo-se no continente americano como herbívoros dominantes. Esses insetos sociais praticam a desfolha de espécies vegetais de interesse econômico, com a finalidade de manter a reserva alimentar da colônia, o fungo simbionte Leucocoprinus gongylophorus, um basidiomiceto. Tal fungo pode ser alvo de aplicaçôes de moléculas fungicidas encontradas em metabólitos gerados por bactérias simbiontes (Xenorhabdus e Photorhabdus) de nematoides entomopatogênicos (Steinernema e Heterorhabditis). Por meio do isolamento e da multiplicação em meio caldo triptona de soja (TSB) da bactéria Xenorhabdus szentirmaii (isolado PAM 25), foram realizados testes laboratoriais com tratamentos contendo 10, 25 e $50 \%$ do metabólito obtido no sexto dia de cultivo. Para tanto, o metabólito foi centrifugado e filtrado, gerando um sobrenadante, o qual foi diluído em batata + dextrose + ágar (BDA), para verificar as consequências da exposição do fungo L. gongylophorus em placas de Petri. Os tratamentos de controle apenas com meio BDA e misto (BDA + TSB) também foram conduzidos simultaneamente por 14 dias, a fim de confirmar a eficiência dos metabólitos. Tanto na diluição de 25 e $50 \%$ houve total inibição do fungo simbionte já nos primeiros dias da condução dos testes. Diante dos resultados obtidos, pode-se afirmar que os metabólitos são a causa do efeito inibitório do desenvolvimento do fungo simbionte das formigas-cortadeiras.

PALAVRAS-CHAVE: controle alternativo; Leucocoprinus gongylophorus; nematoides entomopatogênicos. 
Nature presents a variety of organisms that are detrimental to human agriculture. Chemical pesticides have been widely used to control such pests, however these pesticides damage the environment. To avoid the problems caused by chemical pest control, one alternative is the development of efficient biological control methods. This phenomenon, also known as biocontrol, involves other living organisms to control specific populations, which are considered plagues. For this, natural enemies are expected to be efficient, as they evolved interacting with the target organism and, to some extent, are able to overcome the organism's defenses (FOLGARAIT et al., 2011). Furthermore, the use of microorganisms in biological control has been widely encouraged, as they are easily cultivated and manipulated.

Controls that use synthetic chemicals in their formulations have been increasingly criticized (GILLJAM et al., 2016), since they lead to the accumulation of persistent waste in the environment. Therefore, society pressures researchers to find methods for managing agricultural pests in a more sustainable and harmonious way within agroecosystems. Currently, the most widespread method for controlling leaf-cutter ants is through attractive granular baits (BRITTO et al., 2016). The use of liquid insecticides, powder insecticides, or those applied by thermal foggers are already considered obsolete. Organic producers lack viable options for controlling leafcutter ants, since the Agricultural and Food Inspections and Certifications (Inspeções e Certificações Agropecuárias e Alimentícias-IBD), the largest certifier in Latin America and the only Brazilian certifier of organic products, only approved Bioisca with the plant Tephrosia chandran for this purpose. In addition, the effectiveness of botanical extracts to control ants is questionable (CATALANI et al., 2017).

The fungus-growing ants belong to the Attini tribe. Only taking into account the species that practice such fungi culture (subtribe Attina, the attines), this group presents 15 genera and about 300 species (JEŠOVNIK et al., 2016). The association between ants and cultivated fungus is considered a compulsory mutualism, because both organisms present reciprocal adaptations to live, guaranteeing the stability of the interaction. In this mutualism, the fungus provides necessary nutrients for the colony, especially for the ants' larvae. On the other hand, ants guarantee the protection and dispersion of their fungal partner, as well as provide plant substrate for fungal cultivation. These ants are distributed in the Neotropical region, from the southern United States to northern Argentina (MEHDIABADI; SCHULTZ, 2010). The most derived Attines are the leaf-cutter ants, that use fresh leaves and flowers to cultivate mutualist fungus (Leucocoprinus gongylophorus) (CARLSON et al., 2018). Therefore, these ants are considered agricultural pests, as they damage aerial parts of plants in the environments where they forage (DELLA LUCIA, 2011). The foraging behavior is accomplished by cutting and transporting plant substrate, which, inside the colony, is processed and incorporated into the fungal garden by the colony's garden operators, and maintains the food reserve (WEBER, 1972).

Structured by the queen shortly after the nuptial flight, the colony of Atta leaf-cutter ants originates from the queen's claustral phase in the ground, when she solitarily maintains a fragment of the symbiotic fungus (L. gongylophorus) from her previous colony matrix (WHEELER, 1906). After laying the first eggs, the first workers emerge and mature, and help expand the chambers that act as the garbage and fungal garden for the colony (DELLA LUCIA, 2011).

Entomopathogenic fungi are the most commonly studied and are used as natural sources of insecticides (TRAVAGLINI, 2017). However, several species of entomopathogenic nematodes (NEPs) can be used in pest control, classified in two genera: Heterorhabditis and Steinernema (ALMENARA et al., 2012). Entomopathogenic bacteria associated with the NEPs present an extensive repertoire of genes involved in the production of toxins and secondary metabolites (MS). These molecules are thought to be responsible for ensuring the pathogenic process for the insect and invasion inside the host's body, as well as the maintenance of symbiosis with nematodes (CLARKE, 2008). Recent studies have shown that phytopathogenic fungi (Alternaria, Botrytis, Cochliobolus, Fusarium, Geotrichum, Penicillium, Sclerotina and Phytophthora) damage agriculture (DONG et al., 2006) and are inhibited by metabolites produced by bacteria associated with NEPs (FANG et al., 2014; HAZIR et al., 2016). Therefore, such bacteria could be a new alternative for attine ant management, as these insects maintain an intimate symbiotic relationship with fungus.

The inhibitory effect of bacteria from the genus Xenorhabdus on some phytopathogenic fungi has been recorded in previous studies (CHEN et al., 1994; BÖSZÖRMÉNYI et al., 2009). For Photorhabdus spp., antimicrobials 2-isopropyl-5-(3-phenyl-oxiranil)-benzeno-1, 3-diol, 3, 5, di-hydroxy-4-isopropylstilbene and $\beta$-lactama carbapenem (HU et al., 2006; BODE, 2009) have been reported.

There is great potential for cultivation of NEPs through fermenters (TAVARES et al., 2007) and associated bacteria through liquid cultivation medium, which allows for large scale production with low costs (SHAPIRO-ILAN et al., 2014). In addition, the molecules of metabolites produced by bacteria have already been identified, as is the case for trans-cinnamicacid (TCA), a bio-fungicide with proven action (BOEMARE; AKHURST, 2006), along with other antimicrobial compounds (MCINERNEY et al., 1991) present in this study.

Considering advances in research designed to promote biological control and the possibilities of new application technologies, we conducted a preliminary study aiming to control leaf-cutter ants of the species Atta sexdens (Forel, 1908). For this, we evaluated the inhibition of the fungus cultivated by these insects in the presence of metabolites produced by bacteria of the genus Xenorbabdus. 
The bacteria Xenorhabdus szentirmaii PAM 25, used in the experiments, were kept in the collection of the Laboratory of Biological Control at Instituto Biológico. Such cultures were plated in nutrient bromothymol blue agar (NBTA) and then tryptic soy broth (TSB) medium, in which they were kept at $28^{\circ} \mathrm{C}$ and agitated at $150 \mathrm{rpm}$ for six days, to concentrate the maximum amount of secondary metabolites in the medium.

Previous tests were carried out to verify the susceptibility of the fungal symbiotic of leaf-cutter ants $A$. sexdens to the PAM 25 bacteria. For this, we used four mini colonies from the colony maintained in the Laboratory of Social-Pest Insects (LISP) at São Paulo State University "Júlio de Mesquita Filho" (UNESP), Campus Botucatu (FORTI et al., 1994). Each mini colony contained about $250 \mathrm{~mL}$ of symbiotic fungus garden and received $1 \mathrm{~mL}$ of TSB cultivation medium with bacteria, which was applied directly to the fungus garden with a pipette. After one week, the volume of the symbiotic fungus reduced to half the initial volume in three of the four colonies.

We conducted a second test to evaluate whether the inhibition of $L$. gongylophorus FF2006 growth caused by the bacteria PAM 25 depended on the bacterial presence or on the presence of metabolites produced by the bacteria. This in vitro bioassay consisted of pure cultures of $L$. gongylophorus FF2006 (Microbial Resource Center code - CRM-UNESP), cultivated in cultivation media with the metabolites produced by PAM 25. This bioassay was created in the Laboratory of Fungi Ecology and Systematics (LESF), at UNESP Rio Claro. First, bacteria were grown in TSB for six days, with agitation of $350 \mathrm{rpm}$. After that period, the bacteria cultivation medium was centrifuged at 3,800 rpm for 1 hour. The cultivation medium with the secondary metabolites was then separated from the bacterial biomass and filtered with cellulose paper of $0.22 \mu \mathrm{m}$. The suspension containing the metabolites was then diluted in potato + dextrose + agar (PDA) medium in the proportions of $10 \%(18 \mathrm{~mL} \mathrm{PDA}+2 \mathrm{~mL}$ of metabolites per plate), $25 \%(15 \mathrm{~mL}$ of PDA $+5 \mathrm{~mL}$ of metabolites per plate), and $50 \%(10 \mathrm{~mL}$ of PDA $+10 \mathrm{~mL}$ of metabolites per plate) and poured into Petri dishes for the diffusion test. Six mm fragments of L. gongylophorus FF2006 were inoculated in the center of each plate ( $\mathrm{n}=10$ for each treatment), which were incubated in the dark at $25^{\circ} \mathrm{C}$ for 14 days. Two negative controls were performed, in which the FF2006 mutualist fungus was cultivated: in PDA medium; and in a PDA medium plus TSB medium (1:1).

The final mycelial growth areas (after 14 days of cultivation) of L. gongylophorus FF2006 were scanned with an HP Deskjet 2050 scanner (600 dpi resolution). In addition, the plates were photographed with a digital camera. Using the scanned images, the mycelial growth areas were measured in the ImageJ v. 1.6.0_24 software (ABRÀMOFF et al., 2004). The data was statistically analyzed using the non-parametric Mann-Whitney test, in the R version 3.3.1 software (R CORE
TEAM, 2016), which compared the mycelial growth of the mutualist fungus in the presence of the three different metabolite concentrations: 10,25 and $50 \%$ with negative controls.

Due to the decrease in the fungal garden volume (Fig. 1), that is, the decline of the colony's food reserve to half the initial volume $(250 \mathrm{~mL})$ after one week of exposure to TSB medium in three of the four mini colonies exposed, we sought to understand whether this effect was caused by the presence of bacteria or by the presence of the metabolites produced by bacteria.
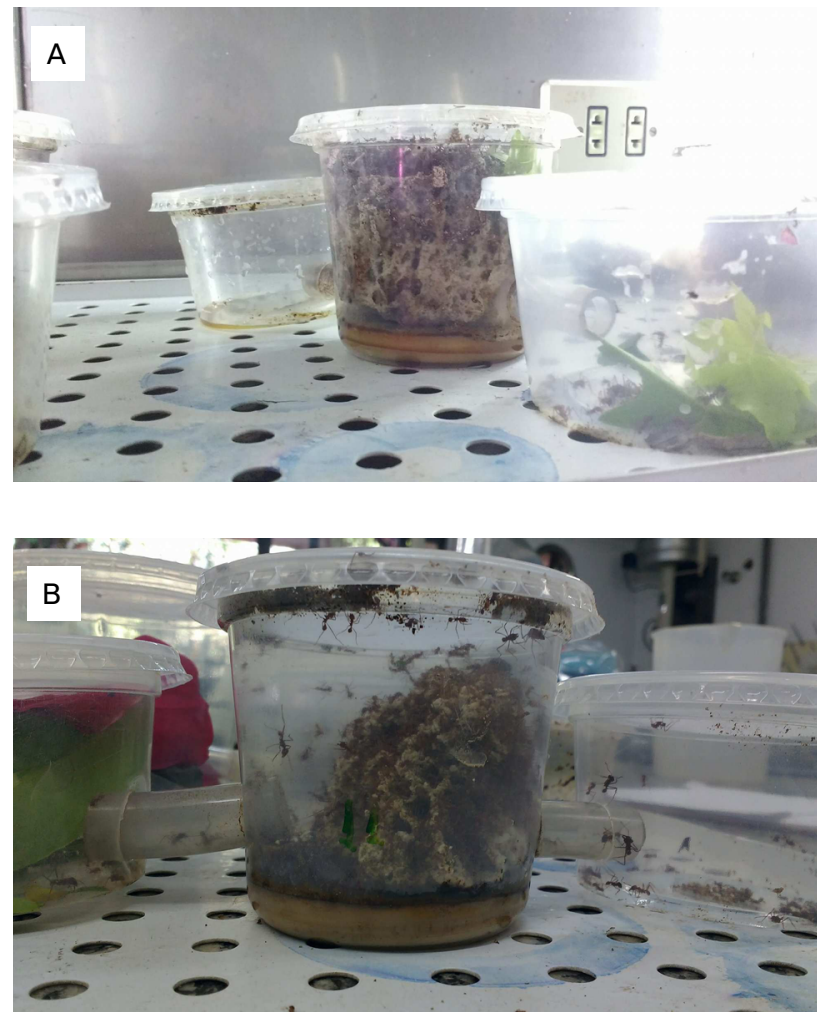

C
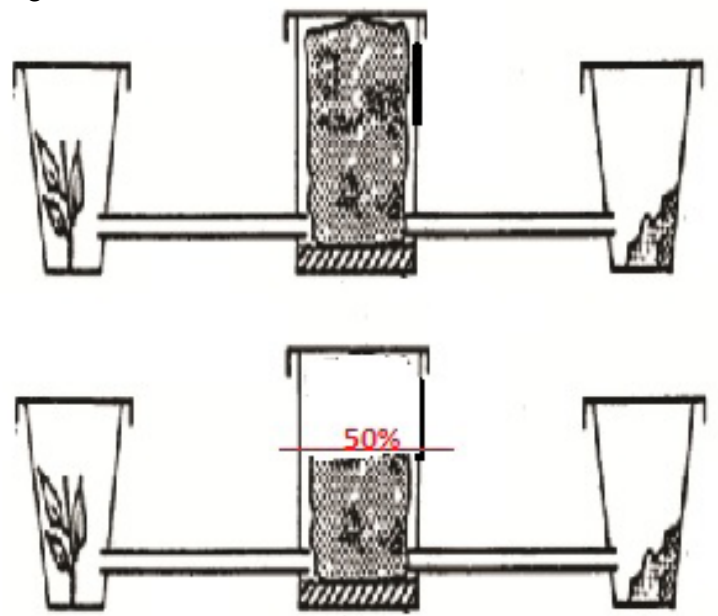

Figure 1. Mini colony: before (A) and after (B) one week exposure to $1 \mathrm{~mL}$ of tryptic soy broth (TSB) cultivation medium with bacteria. (C) Representation by Forti et al., 1994. 
After conducting the diffusion tests (Fig. 2), with statistical analysis applied, we observed a significant difference in mycelial growth of L. gongylophorus in both controls. Therefore, the presence of the TSB medium was detrimental to the growth of this fungus. However, the difference was small $(\mathrm{p}=0.01)$. The significant difference for the comparative analysis of both controls with the $10 \%$ metabolites treatment was very large ( $p>0.00001)$. As for the treatment with metabolites at $25 \%$, the mutualist fungus died after 24 hours of incubation, and all the mycelium on the plug degenerated, as well as in the treatment with concentration 50\% (Table 1).

DE PAULA et al. (2006) used the supernatant of the bacteria Photorhabdus temperata K122, and verified the susceptibility to pathogenicity, as well as the behavioral effect post exposure, of leaf-cutter ants Acromyrmex subterraneus subterraneus and Atta laevigata (Hymenoptera: Formicidae) after topical application of the bacteria in the gaster region. Therefore, we suggest the fungus as the main target for application, through attractive capsules (TRAVAGLINI et al., 2017) or broth (COLELLA et al., 2016).

Bacteria associated with NEPs, Photorhabdus and Xenorhabdus, that produce fungicidal metabolites (HAZIR et al., 2016; FANG et al., 2014), are candidates for controlling the symbiotic fungus and circumvent the morphological, mechanical, and biochemical defenses of leaf-cutter ants (KERMARREC, 1986). Herein, such bacteria were used to contaminate the ants' food reserve, since

Table 1. Mycelial growth area of Leucocoprinus gongylophorus FF2006 $\left(\mathrm{cm}^{2}\right)$ and standard error in the five treatments used in this study.

\begin{tabular}{lccc}
\hline Treatment & $\begin{array}{c}\text { Mycelial } \\
\text { area }\end{array}$ & P1 & P2 \\
$\begin{array}{l}\text { a) Control O1 } \\
\text { (PDA) }\end{array}$ & $4.14 \pm 0.21$ & & 0.018 \\
\hline $\begin{array}{l}\text { b) Control 02 } \\
\text { (PDA + TSB) }\end{array}$ & $3.43 \pm 0.06$ & 0.018 & \\
\hline $\begin{array}{l}\text { c) } 10 \% \text { de } \\
\text { metabolites }\end{array}$ & $1.26 \pm 0.05$ & $>0.00001$ & $>0.00001$ \\
\hline $\begin{array}{l}\text { d) } 25 \% \text { de } \\
\text { metabolites* }\end{array}$ & 0 ** & & \\
\hline $\begin{array}{l}\text { e) } 50 \% \text { de } \\
\text { metabolites* }\end{array}$ & $0^{* *}$ & & \\
\hline
\end{tabular}

PDA: potato + dextrose + agar; TSB: tryptic soy broth; statistics obtained with a non-parametric Mann Whitney $(p<0,05)$. P1: $p$ obtained from paired comparisons of different treatments to the Control 01; P2: values obtained from paired comparisons of different treatments to the Control 02; *metabolites produced by the bacteria Xenorhabdus sp. in TSB cultivation medium for six days; **no mycelial growth.

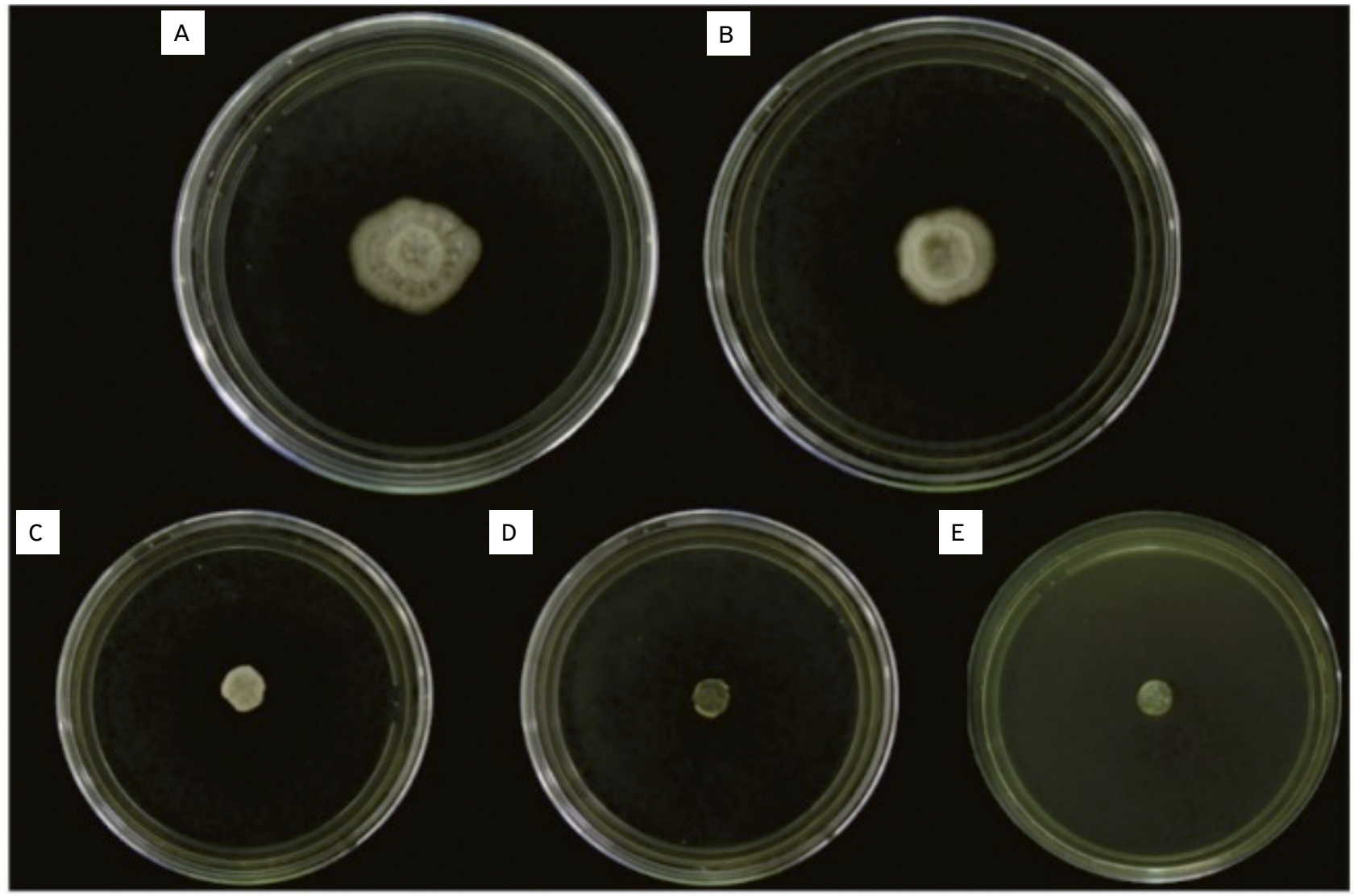

Figure 2. Illustration of mycelial area. Treatments: (A) Control 01 PDA, (B) Control 02 (PDA+TSB), (C) metabolites 10\%, (D) metabolites 20\%, (E) metabolites 50\%. 
this reasoning was already considered for endophytic bacteria (GONZAGA, 2012).

As proven in the diffusion test, the symbiotic fungus (L. gongylophorus) was susceptible to all concentrations and died at high concentrations (25 and 50\%) of the secondary metabolites from the bacterium $X$. szentirmaii PAM 25. Furthermore, such supernatant acted indirectly, promising to control leaf-cutter ants even without the bacterium. Our methods were similar to those from other studies about bioactive extraction with the fungi Trichoderma spp., to inhibit other phytopathogenic fungi from different families (ISAIAS et al., 2014). Therefore, we indicate another control alternative that uses secondary metabolites and contribute to the implementation of this promising line of research.

\section{ACKNOWLEDGEMENTS}

We thank the professors André Rodrigues and Luiz Carlos Forti, for providing materials for this study and allowing access to laboratories for tests. We thank Hannah Doerrier for the translation. This study was financed in part by the Coordenação de Aperfeiçoamento de Pessoal de Nível Superior (CAPES), from Brazil, Finance Code 001.

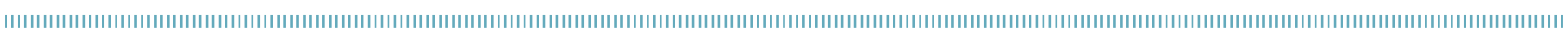
REFERENCES

ABRÀMOFF, M.D.; MAGALHÃES, P.; RAM, S.J. Image processing with Image J. Biophotonics International, v. 1 1, n.7, p.36-42, 2004.

ALMENARA, D.P.; ROSSI, C.; NEVES, C.M.R.; WINTER, C E. Nematoides entomopatogênicos. In: SILVA NETO, M.A.C. da; WINTER, C.; TERMIGNONI, C. (Ed.). Tópicos avançados em entomologia molecular. Rio de Janeiro: INCT-EM, 2012. p. 1-40.

BODE, H.B. Entomopathogenic bacteria as a source of secondary metabolites. Current Opinion in Chemical Biology, v.13, n.2, p. 1 7, 2009. doi: 10.1016/j.cbpa.2009.02.037

BOEMARE, N.E.; AKHURST, R.J. The genera Photorhabdus and Xenorhabdus. In: WORKIN, M.; FALKOW, S.; ROSENBERG, E.; SCHLEIFER, K.H.; STACKEBRANDT, E. (Eds.). The prokaryotes. New York: Business Media Inc., 2006. p. 451-494.

BÖSZÖRMÉNYI, E.; ERSEK, T.; FODOR, A.; FODOR, A.M.; FÖLDES, LS.; HEVESI, M.; HOGAN, J.S.; KATONA, Z.; KLEIN, M.G.; KORMÁNY, A.; PEKÁR, S.; SZENTIRMAI, A.; SZTARICSKAI, F.; TAYLOR, R.A. Isolation and activity of Xenorhabdus antimicrobial compounds against the plant pathogens Erwinia amylovora and Phytophthora nicotianae. Journal of Applied Microbiology, v.107, n.3, p.746-759, 2009. doi: 10.1111/j.1365-2672.2009.04249.x

BRITTO, J.S.; FORTI, L.C.; OLIVEIRA, M.A.; ZANETTI, R.; WILCKEN, C.F.; ZANUNCIO, J.C.; LOECK, A.E.; CALDATO, N.; NAGAMOTO, N.S.; LEMES, P.G.; CAMARGO, R.S. Use of alternatives to PFOS, its salts and PFOSF for the control of leaf- cutting ants Atta and Acromyrmex. International Journal of Research in Environmental Studies, v.3, n.2, p. 11 -92. 2016.

CARLSON, A.L.; ISHAK, H.D.; KURIAN, J.; MIKHEYEV, A.S.; GIFFORD, I.; MUELLER, U.G. Nuclear populations of the multinucleate fungus of leafcutter ants can be dekaryotized and recombined to manipulate growth of nutritive hyphal nodules harvested by the ants. Mycologia, v.109, n.5, p.832-846, 2018. DOI: $10.1080 / 00275514.2017 .1400304$
CATALANI, G.C.; SOUSA, K.K.A.; STEFANELLI, L.E.P.; TRAVAGLINI, R.V.; FORTI, L.C. Estudos com plantas inseticidas para controle de formigas cortadeiras. In: BALDIN, E.L.L.; KRONKA, A.Z; SILVA, I.F. (Org.). Inovação em manejo fitossanitário. 1. ed. Botucatu: Fundação de Estudos e Pesquisas Agrícolas e Florestais. v.1. p. 5-232, 2017.

CHEN, G.; DUNPHY, G.B.; WEBSTER, J. M. Antifungal activity of 2 Xenorhabdus species and Photorhabdus luminescens, bacteria associated with the nematodes Steinernema Species and Heterorhabditis megidis. Biological Control, v.4, n.2, 157-162, 1994.

CLARKE, D.J. Photorhabdus: a model for the analysis of pathogenicity and mutualism. Cellular Microbiology, v.10, n.1 1, p.2159-2167, 2008. doi: $10.1111 /$ j.1462-5822.2008.01209.x

COLELLA, J.C.T.; NASCIMENTO, L.E.; SILVA, E.V.; VIEIRA S.A.; GOMES, M. C. R. Utilização de manipueira para manejo de formiga cortadeira em zona urbana. Journal of Exact Sciences, v. 10, n. 1, p.05-10, 2016.

DE PAULA, A.R.; VIEIRA, L.P.P.; DÁTTILO, W.F.C.; CARNEIRO, C.N.B.; ERTHAL JORR, M.; BRITO, E.S.; SILVA, C.P.P.; SAMUELS, R.I. Patogenicidade e efeito comportamental de Photorhabdus temperata K 122 nas formigas cortadeiras Acromyrmex subterraneus subterraneus e Atta laevigata (Hymenoptera: Formicidae). $O$ Biológico, v.68, p.311-413, 2006.

DELLA LUCIA, T.M.C. Formigas cortadeiras: da bioecologia ao manejo. $1^{\text {st }}$ ed. Viçosa: UFV, 2011 . p. 27-48.

DONG, H.; ZHANG, X.; CHOEN, Y.; ZHOU, Y.; LI, W.; LI, Z. Dry mycelium of Penicillium chrysogenum protects cotton plantsagainst wilt diseases and increases yield under field conditions. Crop Protection, v.25, n.4, p.324-330, 2006.

FANG, X.L.; ZHANG, M.R.; TANG, Q.; WANG, Y.H.; ZHANG, X. Inhibitory effect of Xenorhabdus nematophila TB on plant pathogens Phytophthora capsici and Botrytis cinerea in vitro and in planta. Scientific Reports, v.4, n.4300, 2014. 
FOLGARAIT, P.; GOROSITO, N.; POULSEN, M.; CURRIE, C.R. Preliminary In Vitro Insights into the Use of Natural Fungal Pathogens of Leaf-cutting Ants as Biocontrol Agents. Current Microbiology, v.63, n.3, 250-258, 2011.https://doi.org/10.1007/ s00284-01 1-9944-y

FORTI, L.C.; PRETTO, D.R.; GARCIA, I.P. Aprimoramento de metodologias experimentais para controle de formigas cortadeiras. CURSO DE ATUALIZAÇÃO NO CONTROLE DE FORMIGAS CORTADEIRAS, 3., Anais... PCMIP/IPEF, 1994. p.14-23.

GILLJAM, J.L.; LEONEL, J.; COUSINS, I.T.; BENSKIN, J.P. IS ongoing Sulfluramid use in South America a significant source of Perfluorooctanesulfonate (PFOS)? Production inventories, environmental fate, and local occurrence. Environmental Science (2) Technology, v.50, n.2, p.653-659, 2016. DOI: 10.1021/ acs.est.5b04544

GONZAGA, A.D. Antagonismo de bactérias endofíticas de plantas da Amazônia contra o jardim de fungos associados a formigas cortadeiras Atta sexdens Hymenoptera (Formicidae: Attini). 2012. Tese (Doutorado em Biotecnologia) — Universidade Federal do Amazonas, Manaus, 2012

HAZIR, S.; SHAPIRO-ILAN, D.I.; BOCK, C.H.; HAZIR, C.; LEITE, L.G.; HOTCHKISS, M.W. Relative potency of culture supernatants of Xenorhabdus and Photorhabdus spp. on growth of some fungal phytopathogens. European Journal of Plant Pathology, v.146, n.2, 369-381, 2016. https://doi.org/10.1007/ s10658-016-0923-9

HU, K.; LI, J.; LI, B.; WEBSTER, J. M.; CHEN, G. A novel antimicrobial epoxide isolated from larval Galleria mellonella infected by the nematode symbiont, Photorhabdus luminescens (Enterobacteriaceae). Bioorganic \& Medicinal Chemistry, v. 14, n.13, p.4677-4681, 2006. DOI: 10.1016/j.bmc.2006.01.025

ISAIAS, C.O.; MARTINS, I.; SILVA, J.B.T.; SILVA, J.P.; MELLO, S.C.M. Ação antagônica e de metabólitos bioativos de Trichoderma spp. contra os patógenos Sclerotium rolfsii e Verticillium dahliae. Summa Phytopathologica, v.40, n. 1, p.34-41, 2014.

JEŠOVNIK, A.; GONZÁLEZ, V.L.; SCHULTZ, T.R. Phylogenomics and divergence dating of fungus-farming ants (Hymenoptera: Formicidae) of the genera Sericomyrmex and Apterostigma. PLoS ONE, v.11, n.7, eO151059, 2016. doi: 10.1371/journal. pone.0151059
KERMARREC, A.; FEBUAY, G.; DECHARME, M. Protection of leafcutting ants from biohazards: is there a future for microbiological control? In: LOFGREN, C.S.; VANDER MEER, R.K. (Eds.) Fire ants and leaf-cutting ants: biology and management. Westview studies in insect biology. Studies in Insect Biology. University of Michigan: Westview Press, 1986. p.339-356.

MCINERNEY, B.V.; TAYLOR, W.C.; LACEY, M.J.; AKHURST, R.J.; GREGSON, R.P. Biologically active metabolites from Xenorhabdus spp., Part 2. Benzopyran-1-one derivatives with gastroprotective activity. Journal of Natural Products, v.54, n.3, p.785-795, 1991. DOI: $10.1021 / \mathrm{np50075a006}$

MEHDIABADI, N.J.; SCHULTZ, T.R. Natural history and phylogeny of the fungus-farming ants (Formicidae: Myrmicinae: Attini). Myrmecological News, n.13, p.37-55, 2010.

R CORE TEAM. $R$ : a language and environment for statistical computing. Áustria: R Foundation for Statistical Computing, 2016.

SHAPIRO-ILAN, D.I.; BOCK, C.H.; HOTCHKISS, M.W. Suppression of pecan and peach pathogens on different substrates using Xenorhabdus bovienii and Photorhabdus luminescens. Biological Control, v.77, p.1-6, 2014. https://doi.org/10.1016/j. biocontrol.2014.05.010

TAVARES, F.M.; BATISTA FILHO, A.; LEITE, L.G.; ALMEIDA, L.C.; SILVA, A.C.; AMBRÓS, C.M.G. Efeito de Heterorhabditis indica e Steinernema sp. (Nemata: Rhabditida) sobre larvas do bicudo da cana-de-açúcar, Sphenophorus levis (Coleoptera: Curculionidae), em laboratório e casa-de-vegetação. Nematologia Brasileira, Piracicaba, v.31, n.1, p.12-19, 2007.

TRAVAGLINI, R.V.Bases para o controlemicrobiano de formigas cortadeiras. 2017. Tese (Doutorado em Proteção de Plantas) — Universidade Estadual Paulista “Júlio de Mesquita Filho”, Botucatu, 2017.

TRAVAGLINI, R.V.; STEFANELLI, L.E.P.; ARNOSTI, A.; CAMARGO, R.S.; FORTI, L.C. Isca encapsulada atrativa visando controle microbiano de formigas cortadeiras. Tekhne e Logos, v.8, n.3, p. $100-111,2017$

WEBER, N.A. The attines: the fungus-culturing ants. American Scientist, v.60, p.448-456, 1972.

WHEELER, W.M. The queen ant as a psychological study. Popular Science Monthly, v.68, p.291-299, 1906. 